\title{
Identitet Hrvata i hrvatske države u govorima i porukama pape Ivana Pavla II.
}

\begin{abstract}
Skoko Božo, Identitet Hrvata i hrvatske države u govorima i porukama pape Ivana Pavla II. (The Identity of Croats and the Croatian State in the Speeches and Messages of Pope John Paul II). "Poznańskie Studia Slawistyczne" 10. Poznań 2016. Publishing House of the Poznań Society for the Advancement of the Arts and Sciences, pp. 361-376. ISSN 2084-3011.

Starting from the concept of "external branding" of states and nations, the paper analyses the speeches and messages of Pope John Paul II dedicated to Croats and the Croatian state, spoken and published during his pontificate (1978-2005), in order to uncover how he perceived and presented the Croatian identity. The author believes that Pope John Paul II, thanks to his charisma and significant public impact, as well as extensive knowledge of the Croatian identity, contributed greatly to strengthening the recognisability of Croats in the global public and to promote their values, interests and aspirations.
\end{abstract}

Keywords: Croats; Croatia; identity; Pope John Paul II; messages; speeches

\section{Uvod}

Papu Ivana Pavla II. i hrvatski narod vežu posebne veze i iznimno međusobno poštovanje. S jedne strane, hrvatski narod tog papu smatra jednim od najzaslužnijih svjetskih velikana za samostalnost, slobodu i međunarodno priznanje Hrvatske. O tome je napisano mnoštvo izdanja u Hrvatskoj (npr. Tomašević, Galazka 1994; Rukavina 2003; Körbler 2005; Pavičić 2005; Tomašević 2009), a o zahvalnosti, među ostalim, svjedoče i mnogobrojni trgovi i ulice koje nose njegovo ime te spomenici podignuti u čast tog pape. S druge strane, uz mnogobrojna zauzimanja za hrvatske interese, posebice tijekom raspada bivše Jugoslavije i Domovinskog rata, papa Ivan Pavao II. čak je tri puta pohodio Hrvatsku, čime se mogu pohvaliti tek rijetke države svijeta (1994., 1998. i 2003.), a hrvatski narod uzvratio mu je 
veličanstvenim dočecima ${ }^{1}$. O razlozima takvog međusobnog odnosa svojedobno je pisao zagrebački nadbiskup kardinal Franjo Kuharić: „Budući da je hrvatski narod imao sličnu povijest, slična iskustva i slične patnje kao njegov poljski narod, Papa je dobro razumio probleme hrvatskoga naroda, uživljen u njegove muke, zauzet za njegova prava" (Kuharić 1994: 5). Zanimljivo je kako su prvi kontakti Hrvata s budućim papom započeli još dok je bio krakovski nadbiskup te kako je započeo pontifikat s priličnim poznavanjem hrvatske povijesti i izazovne sudbine u okvirima socijalističke Jugoslavije. Godine 1976. tadašnji zagrebački nadbiskup Franjo Kuharić pismeno ga je izvijestio o početku devetogodišnje proslave jubileja „Trinaest stoljeća kršćanstva u Hrvata", a kardinal Wojtyła uzvratio je čestitkom u kojoj hrvatski narod naziva bratskim te podsjeća na dodirne točke u povijesti hrvatskog i poljskog naroda, uključujući i zajedničke vladare te svetu braću apostole Ćirila i Metoda (Nagy 2011: 45). Iste godine kardinal Wojtyła uputio je pismo kardinalu Franji Šeperu, koji je kao papin izaslanik u Solinu predvodio veliko slavlje tisućite obljetnice prve poznate Gospine crkve na hrvatskom tlu, što ju je izgradila kraljica Jelena. U tom pismu od 21. srpnja 1976. papa ističe sličnosti poljskoga i hrvatskoga naroda te uloge žena u povijesti dvaju naroda (kraljice Jelena i Dąbrówka), naglašeno štovanje Blažene Djevice Marije te stoljetne veze sa Svetom Stolicom. U istom pismu Gospu naziva „Kraljicom Hrvata i Kraljicom Poljaka" te ističe dva svetišta - ono u Solinu i Częstochowi (Nagy 2011: 46). Dvije godine kasnije, nekoliko mjeseci prije nego će krakovski kardinal postati papa, Krakov je pohodio zagrebački nadbiskup Kuharić, gdje je zajedno s Wojtyłom predvodio radničko hodočašće u marijansko svetište Piekary te održao propovijed na hrvatskom jeziku. Bila je to prigoda da nadbiskup Kuharić dodatno upozna budućeg papu s tragičnom poviješću i sudbinom hrvatskoga naroda te sa stanjem Crkve u Hrvata pod komunističkim režimom. Prema svjedočenjima sudionika, taj je susret dodatno produbio povezanost Hrvata s budućim papom (Nagy 2011: 47).

Tijekom svoga pontifikata, od 1978. do 2005. papa Ivan Pavao II. uputio je Hrvatima gotovo osam stotina poruka, čestitki, zahvala, sućuti

${ }^{1}$ Iako u Hrvatskoj živi oko 4,5 milijuna ljudi, procjenjuje se kako je na središnjem misnom slavlju pape Ivana Pavla II. tijekom njegova prvog posjeta Zagrebu bilo oko milijun ljudi. 
i govora (ili ih je spomenuo u obraćanjima upućenima svijetu). Među njima je i velik broj poruka koje se tiču hrvatskoga identiteta, vjere, povijesnog hoda, sadašnjosti i budućnosti. Sva su ta obraćanja predmet analize ovoga rada, čiji je cilj istražiti kako je papa Ivan Pavao II. percipirao Hrvate i hrvatsku državu te kako ih je predstavljao svijetu. Pritom je pretpostavka rada kako je taj sveti papa, zahvaljujući svojoj karizmi, načinu komunikacije te popularnosti u svijetu, uvelike utjecao na globalno javno mnijenje, pa tako i na oblikovanje percepcije o pojedinim državama i narodima. Nema dvojbe kako je taj utjecaj bio izrazito pozitivan za Hrvate, budući da je papa Ivan Pavao II. često isticao Hrvate u pozitivnom kontekstu, primjerice kako su Hrvati bili prvi slavenski narod koji se susreo s kršćanstvom, kako su rano uspostavili odnos jedinstvena zajedništva sa Svetom Stolicom, kako su obogatili europsku baštinu, kako su imali tešku povijest, ali su unatoč tome ostali vjerni kršćanskim načelima i vrednotama i sl. Često je u svojim obraćanjima podsjećao kako se papa Ivan X. obratio prvom hrvatskom kralju Tomislavu (910.-930.) nazvavši njegove podložnike „najposebnijim sinovima Svete Rimske Crkve” (specialissimi filii Sanctae Romanae Ecclesiae) te kako je u doba otomanskog prodora u Europu papa Lav X. Hrvatima udijelio naslov „Najčvršći štit i predziđe kršćanstva" (Scutum saldisimum et antimurale christianitatis) (Tomašević 2009: 59). Takvu promociju, posebno u vrijeme socijalističke Jugoslavije kad su teme nacionalnog identiteta bile prešućivane, hrvatski je narod mogao samo sanjati.

\section{Hrvatski identitet u govorima i porukama Ivana Pavla II.}

\subsection{Metodologija i uzorak}

Za potrebe ovoga rada analizirana su sva papina obraćanja tijekom njegova pontifikata upućena Hrvatima, odnosno ona u kojima se Hrvati na izravan ili neizravan način spominju. Svi su ti papini istupi naknadno objavljeni u tiskanim izdanjima, ponajprije u vatikanskom dnevniku „L'Osservatore Romano", a potom u izvješćima IKA-e (Informativna katolička agencija iz Zagreba), katoličkog tjednika „Glasa Koncila”, „Službenom vjesniku zagrebačke nadbiskupije" itd. Posljednjih godina sva su papina 
obraćanja Hrvatima objedinjena u nekoliko knjiških izdanja, od kojih je najcjelovitije Papa Ivan Pavao II. govori Hrvatima iz 2011. koje je uredio p. Božidar Nagy. Takvi su sustavni prikazi uvelike olakšali istraživanje.

Analizirajući te tekstove došli smo do sljedećeg pokazatelja: papa Ivan Pavao II. tijekom svoga pontifikata uputio je ukupno 782 poruke različitog karaktera u kojima se spominju Hrvati ili Hrvatska ili su bili upućeni Hrvatima. Najveći broj je protokolarnih pozdrava i čestitki, a pojavljuju se i govori, poruke, pisma, zahvale, sućuti... Značajno povećanje poruka u odnosu na ranije razdoblje zabilježeno je 1989. (ukupno 34 poruke), što se poklapa s padom komunizma i tzv. proljećem naroda u istočnoj i jugoistočnoj Europi. Rekordan se broj obraćanja dogodio 1994. (60) i 1995. (65), potom 1997. (50), 1993. (48) i 2003. (47). Povećanja možemo povezati s ratnim zbivanjima u Hrvatskoj i Bosni i Hercegovini, kad je papa bio izrazito aktivan u zauzimanju za mir, te s razdobljima koja su bila obilježena posjetima Hrvatskoj. U nekim istupima Hrvati ili Hrvatska spominju se usputno, neke se poruke odnose na Hrvate koji žive izvan Hrvatske, a nekoliko je govora koje možemo smatrati povijesnima. Primjerice, 1979. u prigodi proslave Jubileja kneza Branimira u Rimu, 1983. na kanonizaciji blaženoga Leopolda Mandića, 1984. - radio poruka i pismo u prigodi Nacionalnog euharistijskog kongresa održanog u Mariji Bistrici, 1989. govor prilikom pohoda hrvatskoj crkvi Svetog Jeronima u Rimu, 1992. govor prigodom predaje vjerodajnica prvoga hrvatskog veleposlanika Ive Livljanića pri Svetoj Stolici, 1994. prigodom posjeta Hrvatskoj održao je 6 govora te jedan o Hrvatskoj pred hodočasnicima na općoj audijenciji u Rimu, 1995. u prigodi kanonizacije blaženog Marka Križevčanina u Košicama, 1997. prigodom posjeta Bosni i Hercegovini papa je održao 7 govora te jedan po povratku u Rim, 1998. u prigodi drugog posjeta Hrvatskoj održao je 10 govora te osvrt nakon povratka u Rim, 2003. u prigodi trećeg posjeta Hrvatskoj izgovorio je 8 govora, a nakon povratka u Rim na općoj audijenciji iznio je osvrt na posjet, dok je u prigodi drugog posjeta Bosni i Hercegovini izgovorio tri govora. Većina je govora održana na hrvatskom jeziku. Nakon analize sadržaja svih tih poruka, usredotočili smo se na one u kojima se spominju elementi hrvatskoga identiteta te ćemo prezentirati ključne nalaze, s posebnim osvrtom na njihove opise. 


\subsection{Hrvatski identitet u govorima i porukama Ivana Pavla II. od 1978. do 1990.}

Prvi papin govor na hrvatskom jeziku, a u kojem govori i o hrvatskom identitetu, izgovoren je 30. travnja 1979. u bazilici Svetog Petra u Rimu, gdje je papa predvodio svetu misu s hrvatskim biskupima i hodočasnicima slaveći 1100. obljetnicu izmjene pisama između kneza Branimira i pape Ivana VIII. te blagoslova što ga je daleke 879. papa uputio Branimiru i hrvatskom narodu. U tom govoru posvećenom stoljetnim vezama Hrvatske i Svete Stolice papa ponovno ističe poveznice između Hrvata i Poljaka te spominje „Bijelu Hrvatsku”, koju naziva pradomovinom Hrvata i svojim zavičajem. Spominje sljedeće elemente hrvatskoga identiteta: lijepa i draga zemlja, kršćanski knezovi i kraljevi, starohrvatski liturgijski jezik, divne crkve, svetišta Majke Božje. „Gledajući u duhu bogatu i višestoljetnu povijest" hrvatskoga naroda, papa posebno naglašava tri njezine izvanredne vrednote: vjernost Isusu Kristu i Evanđelju (,,koju su vaši pradjedovi znali iskupiti pravim mučeničkim žarom i duhom, u vjekovnoj borbi za krst časni i slobodu zlatnu"), ljubav i odanost Hrvata prema Rimskoj crkvi, posebno prema Petrovoj Stolici („Ova crkva uistinu je Majka vaša u kojoj su se i preci vaši iz najbistrijeg vrela pojili slatkim napitkom nauka") te odanost i pobožnost Hrvata prema Mariji, Majci Božjoj (,koju vi tako rado nazivate Kraljica Hrvata i sinovski štujete u brojnim svetištima”). Na kraju govora posebno naglašava kako je hrvatski narod iseljenički narod (,Znamo da veliki broj Hrvata živi i radi izvan domovine, po cijelom svijetu”) (Petrač, Šanjek 1995: 31). U tom kontekstu Hrvata kao iseljeničkog naroda vrijedi spomenuti kako se papa u nekoliko navrata tijekom svojih putovanja po svijetu izravno obratio i hrvatskim zajednicama koje su ga dočekivale. Primjerice, tijekom posjeta Njemačkoj 17. studenoga 1980. u Mainzu, tijekom posjeta Austriji 12. rujna 1983. u Beču, tijekom posjeta Kanadi, 15. rujna 1984. u Torontu, tijekom posjeta Venezueli 27. siječnja 1985. u Caracasu (tada je papa rekao: „Živeći daleko od svoje domovine Hrvatske, čuvajte uvijek živu trinaestoljetnu kršćansku i kulturnu baštinu svoga naroda"; Nagy 2011: 94).

Petnaest dana nakon spomenute proslave Branimirova jubileja u Rimu papa je poslao pismo zagrebačkom nadbiskupu Kuhariću i hrvatskim vjernicima, a koje je bilo čitano po hrvatskim crkvama na domovinskom 
dijelu proslave. U pismu od 15. svibnja 1978. papa ponovno podsjeća na stoljetnu vjernost Hrvata Svetoj Stolici te posebno naglašava ulogu kneza Branimira: „Nema sumnje, smjelo djelo kojim je knez Branimir u doba raskola između Istočne i Zapadne Crkve od Bizantskog Carstva svom dušom i srcem prešao na stranu Rima i Zapada, učinilo je stvarnost Hrvatske katoličkom" (Nagy 2011: 54). Naglašavajući vjernost Hrvata papi, Ivan Pavao II. naziva ju to čudesnijom i pohvalnijom što je bila izvrgnuta stoljetnim navalama te trpjela nevolje. Upravo su trpljenje i strpljivost obilježja koja u nastavku govora pripisuje Hrvatima te na njih stavlja svojevrsnu odgovornost da ostanu u savezu s Kristom i Svetom Stolicom te hrabro svjedoče vjeru (Petrač, Šanjek 1995: 33). Nedugo zatim papa Ivan Pavao II. odlazi u Poljsku i slavi misno slavlje u Gnieznu. Tom prigodom, govoreći o slavenskim narodima i njihovu mjestu u Crkvi, papa izvan prethodno pripremljenog govora posebno spominje Hrvate i nedavno slavlje Branimirova jubileja: „Prilikom krštenja Poljske, treba se sjetiti pokrštenja Slavena: Hrvata - s Hrvatima sam nedavno u bazilici svetog Petra na njihovu hrvatskom jeziku zahvalio Bogu za više od tisuću godina, tisuću sto, tisuću tristo godina njihove vjere i njihove vjernosti Svetoj Stolici" (Nagy 2011: 56).

O povezanosti Hrvata i Majke Božje papa je često govorio. Primjerice, obraćajući se hodočasnicima Splitsko-makarske nadbiskupije na putu u Lurd, a 24. rujna 1980. na Trgu svetog Petra u Rimu papa je, među ostalim, rekao: „Poznato nam je da su Hrvati veliki štovatelji Majke Božje, što lijepo izražavaju i pjesnikove riječi uklesane u vašem nacionalnom svetištu u Mariji Bistrici: „Dušo, duše hrvatske, Isusova mati, Sunce naših stradanja, ne prestani sjati!" (Nagy 2011: 61). Obraćajući se mladim Hrvatima u posebnoj audijenciji tijekom Međunarodne godine mladih u Vatikanu, 30. ožujka 1985. papa je naglasio ulogu Majke Božje kao kraljice Hrvata u životu hrvatskoga naroda, a obraćajući se hodočasnicima na Trgu svetog Petra u Rimu 21. travnja 1991., papa je spomenuo pokorničko hodočašće u Gospino svetište u Remetama kraj Zagreba, podsjetivši kako ju narod zove „Vjerna odvjetnica Hrvatske” (Nagy 2011: 150). Prigodom susreta s crkvenim i državnim odborom Republike Hrvatske u posebnoj audijenciji zahvale za njegov prvi pohod Hrvatskoj 7. travnja 1995., papa Ivan Pavao II. povjerio je hrvatsku domovinu „Najvjernijoj odvjetnici Hrvatske (Advocatae Croatiae fidelissimae)”, baš kao i 31. siječnja 1997. obraćajući 
se predstavnicima nadbiskupije, grada i sveučilišta u Zadru u posebnoj audijenciji u povodu 600. obljetnice zadarskoga sveučilišta. Gospu kao kraljicu Hrvata i vjernu odvjetnicu Hrvatske papa je spomenuo u još nekoliko navrata. Na susretu s predstavnicima zborova iz Hrvatske u Vatikanu 29. rujna 1985. papa se spomenuo povezanosti Hrvata i glazbe te jednog starog hrvatskog običaja: „Poznato mi je koliko hrvatski narod voli glazbu i kako običan narod sudjeluje u crkvenom pjevanju... Dapače, običaj je da hrvatski seljaci, uz Marijine pjesme, kojima obilujete, obrađuju svoja polja i tako radom i molitvom - pjesmom slave Gospodina" (Nagy 2011: 100).

U prigodi 1500. obljetnice rođenja svetog Benedikta, 21. ožujka 1981., papa se u Vatikanu na hrvatskom jeziku obratio hrvatskim i slovenskim hodočasnicima te posebno istaknuo ulogu svetih Ćirila i Metoda u evangelizaciji slavenskih naroda i razvoju Europe, spomenuvši biskupa đakovačkog Josipa J. Strossmayera, koji je predvodio hodočašće u znak zahvalnosti za njihovo proglašenje svecima sveopće Crkve prije 100 godina. Uloga Ćirila i Metoda u evangelizaciji slavenskih naroda bila je tema i obraćanja mladima iz Šibenika i Subotice na posebnoj audijenciji u Vatikanu 28. lipnja 1985. te u nizu drugih prigoda.

Završavajući devetogodišnju proslavu jubileja Trinaest stoljeća kršćanstva u Hrvata, u Mariji Bistrici je 8. i 9. rujna 1981. održan Nacionalni euharistijski kongres - NEK. Tom je prigodom papa Ivan Pavao II. hrvatskim vjernicima uputio poruku putem Radija Vatikan, a potom i pismo, koje je bilo pročitano pred sudionicima Kongresa. U tom opsežnom pismu papa se, među ostalim, spominje hrvatske povijesti:

Početkom sedmog stoljeća vaši pređi, stigavši iz karpatskog područja Bijele Hrvatske
- nedaleko od mog rodnog mjesta - dođoše u sadašnju vašu Lijepu Domovinu, stupivši
u dodir s kršćanstvom, što se u ovim vašim krajevima već bilo duboko ukorijenilo još
od apostolskih vremena. Zemlja natopljena krvlju solinskih, istarskih, sisačkih i toli-
kih mučenika, postala je domovinom vašeg naroda. Primajući krštenje i ispovijedajući
jedinu apostolsku, rimokatoličku vjeru, Hrvati dođoše također i u dodir sa zapadnom
rimskom kulturom, te postadoše tako sastavnim dijelom kršćanskih naroda Europe,
koja se upravo tada oblikovala u duhovnu i kulturnu cjelinu (Petrač, Šanjek 1995: 36).

U tom govoru papa je ukazao i na dva elementa hrvatskog identiteta: Hrvati su se odlikovali brojnim potomstvom (,iako su obitelji vaših pređa živjele u težim i siromašnijim vremenima”, „Ne dopustite da među vama prevlada sebičnost i kultura smrti!"), Hrvati bi trebali biti narod koji 
spaja i povezuje (,Božja Providnost postavila je vaš narod između Zapada i Istoka, u dodir s različitim narodima i kulturama, i stoga s nekim zvanjem i poslanjem posredništva"), hrvatske katoličke obitelji trebale bi promicati svetost (papa je spomenuo program hrvatskih biskupa iz Nina „Hrvatska katolička obitelj dnevno moli i nedjeljom slavi svetu misu"), odanost Majci Božjoj (papa je spomenuo glavna Marijanska svetišta u Hrvatskoj i BiH) te patnička prošlost hrvatskoga naroda (,Taj drveni kip ([Majke Božje Bistričke]), što ga vaši pređi bijahu prisiljeni skrivati zbog opasnosti od oskvrnuća i uništenja, predstavlja u izvjesnom smislu svu patničku povijest vašeg naroda tijekom trinaest minulih stoljeća"). Kao opće uzore iz hrvatskoga naroda papa je spomenuo svetog Leopolda Bogdana Mandića, kojeg je ranije proglasio svetim.

U posebnom pismu mladima, pročitanom na domovinskom slavlju Međunarodne godine mladih, u zagrebačkoj katedrali 27. listopada 1985. papa Ivan Pavao II. ponovno podsjeća kako je vjeru u Isusa Krista „hrvatski narod primio prije trinaest stoljeća, prvi među slavenskim narodima”. Istodobno je ukazao na posebno poslanje mladih Hrvata:

Vi mladi katolici, jer živite na susretištu Istoka i Zapada, u dodiru sa različitim narodima i kulturama u zemlji, kao što je Jugoslavija (...), posebno ste pozvani da u potpunoj svijesti svoga vjerskog, kulturnog i nacionalnog identiteta razvijate dijalog s kršćanima drugih vjeroispovijesti, s muslimanima te s onima koji ne vjeruju (Nagy 2011: 102).

Obraćajući se mladima iz Zadarske nadbiskupije na svetoj misi u Rimu 14. prosinca 1985. papa se spomenuo i svoga prethodnika pape Siksta V. nazvavši ga „velikim dobrotvorom Hrvata”. A o drugom velikanu, kojeg Hrvati smatraju svojim jer je rođen na području današnje Dalmacije - svetom Jeronimu, papa je govorio 21. listopada 1989. u prigodi posjeta crkvi i Papinskom hrvatskom zavodu svetog Jeronima u Rimu. U propovijedi ga je nazvao „vašim suzemljakom, velikim Dalmatincem, osobitim uzorom pobožnosti i služenja riječi”. Spominjući kako je papa Siksto V. podigao to zdanje u znak poštovanja prema svetom Jeronimu i hrvatskoj zajednici, podsjetio je kako ta „,rkva za hrvatsku zajednicu u Rimu predstavlja živi spomen i trajno svjedočanstvo otačke drevne vjere i kršćanskih običaja. Narod je Hrvatske ostao u njima čvrst tijekom složenih i teških povijesnih zbivanja, što su zemlju i narod stavili na teška iskušenja...”. U zadnjem je dijelu propovijedi podsjetio kako Hrvati žive po cijelom svijetu te dodao: 
„Povijest Hrvatske, kao što dobro znate bila je često prožeta nevoljama i kušnjama svake vrste, ali upravo u najtvrđim poteškoćama uvijek ste znali uzdići i očuvati u domovini znakove nade u Boga u brojnim svetištima, crkvama i kapelicama koje su razasute po vašoj zemlji" (Petrač, Šanjek 1995: 40).

\subsection{Poruke Ivana Pavla II. tijekom posjeta Hrvatskoj}

Iznimno važni za „vanjsko brendiranje” Hrvatske, poglavito u katoličkom svijetu, bili su posjeti pape Ivana Pavla II. 1994., 1998. i 2003., koji uvijek privlače pozornost svijeta. Pritom treba imati u vidu rijetkost činjenice da poglavar Katoličke crkve u relativno kratkom povijesnom razdoblju pohodi više puta jedan narod, kao što je bio slučaj s hrvatskim narodom. Tijekom svih triju papinih posjeta, Hrvatska je, uglavnom u pozitivnom kontekstu, bila jedna od glavnih vijesti u svim svjetskim medijima. Sveti Otac je tijekom pohoda Hrvatskoj otvoreno lobirao za ulazak Hrvatske u Europsku uniju, ističući kako će „,bogata hrvatska baština pridonijeti učvršćenju Unije, bilo kao upravne i teritorijalne cjeline, bilo pak kao kulturne i duhovne stvarnosti" (Skoko 2003: 377).

U rujnu 1994. papa je Hrvatsku pohodio kao „hodočasnik pomirenja”. Stigao je u Zagreb u godini u kojoj je zagrebačka nadbiskupija slavila 900. obljetnicu svoga osnutka. U pozdravnom govoru u zagrebačkoj zračnoj luci, podsjetio je kako je

već prije doseljenja Hrvata u ove krajeve, riječ Evanđelja bila posijana u carskim provincijama Dalmacije i Panonije. Nju su - prema svjedočanstvu Konstantina Porfirogeneta - počeli prihvaćati i vaši preci u vrijeme cara Heraklija i pape Agatona, u VII. stoljeću. Odnosi između Hrvatske i Svete Stolice bivali su sve prisniji, posebno nakon što se u IX. stoljeću, u vrijeme kneza Branimira i pontifikata Ivana VIII. učvrstila hrvatska država (Petrač, Šanjek 1995: 167).

Istodobno je podsjetio i na ulogu svete solunske braće Ćirila i Metoda u evangelizaciji i širenju kulture među Slavenima: „I u nekim područjima Hrvatske, njihova djelatnost ostavila je neizbrisive tragove, u liturgiji i na jezičnom polju - posebno u glagoljskoj tradiciji”. Ponovno je podsjetio na tešku hrvatsku povijest: „Tijekom stoljeća kršćani ove zemlje, koji su se često morali boriti za «krst časni i slobodu zlatnu» ostali su 
najvećim dijelom vjerni Evanđelju i jedinstvu s rimskim biskupom, unatoč progonstvima i nedaćama svake vrste". U pozdravnom govoru papa je naveo i hrvatske svece i blaženike, posebno ističući zagrebačkog nadbiskupa Alojzija Stepinca - „bedem Crkve u Hrvata” - te druge velikane vjere koji su se „u ime ljudskih prava i kršćanskog dostojanstva suprotstavljali jarmu ateističkog komunizma". Na središnjem misnom slavlju u hrvatskoj metropoli okupilo se oko milijun ljudi, očekujući papin „blagoslov” hrvatskoj državnosti i suverenosti, ali i papin poziv na pomirenje i oprost nakon krvavog rata. U svojoj homiliji na središnjem misnom slavlju na zagrebačkom hipodromu Sveti Otac je istaknuo kako su najstariju ispovijest vjere „Ti si Krist!” (Mk 8,29) među slavenskim narodima upravo prvi izgovorili Hrvati, spominjući se početaka odnosa Hrvata i Svete Stolice (Rukavina 2003; Petrač, Šanjek 1995).

Papa je i tom prigodom govorio o Hrvatima kao narodu koji je pozvan na otvorenost prema drugima:

Nije li povijest stvorila tisuće neraskidivih veza među vašim narodima? [na prostoru bivše Jugoslavije - B.S.] Vaši jezici, iako različiti, nisu li među sobom tako bliski da se međusobno sporazumijevate i razumijete više nego je to slučaj u ostalim dijelovima Europe? I sam zemljopisni položaj balkanskih zemalja nameće se kao graditelj mira, jer su te zemlje obavezan prolaz između Bliskog istoka i Srednje Europe. Upravo zbog toga u prošlim je stoljećima ovdje cvjetala trgovina, razmjena raznih dobara i poduzetništva, i to sve na dobrobit i blagostanje svih.

Dodao je kako napredak i dobro naroda na Balkanu ima samo jedno ime - mir! Na odlasku iz Hrvatske papa je citirao Marka Marulića, oca hrvatske književnosti, a nakon povratka u Rim, Ivan Pavao II. na susretu s hodočasnicima 14. rujna 1994. dao je ponajbolju „definiciju” Hrvata i njihova povijesnog puta, posebno istaknuvši kardinala Stepinca kao „,vrsnog lika Crkve u Hrvata”:

Hrvatski narod bio je prvi slavenski narod koji se susreo s kršćanstvom: za njegovu su evangelizaciju, koja je počela već u VII. stoljeću, skrb vodili misionari pristigli iz Rima, a ta je evangelizacija osjetila i blagotvorni utjecaj svete braće Ćirila i Metoda, apostola Slavena. Hrvatska je nacija vrlo rano uspostavila odnos jedinstvenog zajedništva sa Svetom Stolicom, što se postupno razvijalo i produbljivalo tijekom stoljeća. Papa Ivan X. obratio se prvome hrvatskom kralju Tomislavu nazvavši njegove podložnike „najposebnijim sinovima Svete Rimske Crkve”. U doba Otomanskog prodora u Europu Lav X. je Hrvatima udijelio naslov „Najčvršći štit i predziđe kršćanstva”. To je naslov koji je imao svoje veliko i pravo značenje u povijesti vjere i svetosti koje je 
hrvatski narod znao ostvarivati i što vrlo lijepo pokazuje i u devet stoljeća života zagrebačke Crkve (Petrač, Šanjek 1995: 187).

U listopadu 1998. Sveti Otac je na svome drugom pohodu Hrvatskoj boravio u Zagrebu, Mariji Bistrici, Solinu i Splitu te okupio gotovo dva milijuna ljudi na svojim susretima. Beatifikacija kardinala Alojzija Stepinca, uz proslavu 1700. obljetnice grada Splita, predstavljala je vrhunac papina boravka u Hrvatskoj. Papa Ivan Pavao II. svoje drugo apostolsko putovanje Hrvatskoj označio je kao nastavak putovanja iz 1994. ističući da ovaj put dolazi kao „hodočasnik Evanđelja slijedeći stope prvih svjedoka vjere” s ciljem ,ubiranja plodova njihova hrabrog svjedočenja - od prvih stoljeća kršćanstva do strašnog komunističkog progona”. Papa je naglasio i drugi cilj svojeg dolaska - učvrstiti svoju braću u vjeri. „Životno je važno", istaknuo je Sveti Otac, ,da hrvatski narod ostane vjeran svojim kršćanskim korijenima te da istodobno bude otvoren zahtjevima sadašnjeg trenutka” koji, unatoč silnim teškoćama, daje i „utješne razloge nade”. Nakon ,nasilnoga i krvavoga rata” hrvatski je narod usmjeren, prema Papinim riječima, na „liječenje dubokih rana sukoba, na istinsko pomirenje među svim etničkim, religioznim i političkim komponentama stanovništva i prema uvijek sve većoj demokratizaciji društva”. Uz ratne posljedice papa je naveo i mentalne ostatke komunističkog režima kao razlog stvaranja brojnih zapreka i poteškoća (Rukavina 2003: 96). Papa je, obraćajući se vjernicima na splitskom Žnjanu 4. listopada 1998., naglasio kako su upravo kršćani „danas pozvani dati novo lice svojoj domovini”, posebice na planu etike i morala hrvatskoga društva koje je u zadnjim desetljećima svoje opstojnosti bilo dekadentno zbog vladajućeg totalitarizma i neposrednih ratnih zbivanja. Papa je naglasio kako bez toga nema „ni prave slobode, ni istinske demokracije". U Mariji Bistrici papa je proglasio blaženim kardinala Alojzija Stepinca koji je, „služeći Bogu i narodu” tijekom Drugog svjetskog rata i komunističkog poraća, postao simbolom pravednosti i mučeništva. Papa je beatificirao Stepinca unatoč žestokim otporima mnogih koji se u to vrijeme nisu libili optuživati kardinala za nacionalizam i ustaštvo zbog njegove pozicije na čelu Crkve u Hrvatskoj u doba Nezavisne Države Hrvatske (Papa u Hrvatskoj 2003a).

Obraćajući se vjernicima u Splitu, u prigodi proslave 1700. obljetnice tog grada, papa se prisjetio višestoljetne povijesti kršćanstva na tim 
prostorima te naglasio kako su upravo ,začeci kršćanstva Božjom providnošću oblikovali nacionalnu baštinu ovog naroda", imajući pri tome na umu dvostruki razlog zahvale Bogu: ,za dar poziva na vjeru i njezine plodove, koji se očituju u hrvatskoj kulturnoj baštini sve do današnjih dana”. Uz promotivnu korist koju je Hrvatska ostvarila tim papinim posjetom, ne smijemo zanemariti ni papina lobistička nastojanja - o čemu svjedoči njegova rečenica izgovorena na odlasku u Splitu, 4. listopada 1998.:

Vidio sam društvo koje želi graditi svoju sadašnjost i budućnost na čvrstim temeljima demokracije, u posvemašnjoj vjernosti svojoj povijesti prožetoj kršćanstvom te se s potpunim pravom uključiti u zbor ostalih europskih nacija. S radošću priznajem da ste zemlja, koja se, zadobivši slobodu i svladavši bolno iskustvo rata, ponovno izgrađuje te se revno i odlučno obnavlja materijalno i duhovno.

On je potom, na svoj osobiti način, svoj pogled i riječ upro i prema međunarodnoj zajednici te istaknuo:

Potičem muževe i žene dobre volje diljem svijeta da ne zaborave tragedije koje je doživjelo ovdašnje stanovništvo tijekom svoje povijesti, i to posebno u ovom našem stoljeću. Neka ne izostane stvarna i velikodušna pomoć potrebna pojedincima i obiteljima da bi mogli živjeti u slobodi i ravnopravnosti, s dostojanstvom djelatnih članova ljudske obitelji. Europa je krenula u novi odsjek svojeg jedinstva i rasta. Da bi radost bila potpuna, nitko ne smije biti zaboravljen na putu koji vodi u europski zajednički dom! (Papa u Hrvatskoj 2003a).

Na povratku iz Hrvatske, na općoj audijenciji u Vatikanu, 7. listopada 1998. papa je analizirao svoj pohod Hrvatskoj te je posebno opisao blaženog Stepinca: „U njegovu je liku sažeta cijela tragedija koja je pogodila Europu tijekom ovoga stoljeća, obilježena velikim zlima fašizma, nacizma i komunizma". Posebno je govorio o Solinu, gdje se nalazi najstarije Marijansko svetište u Hrvatskoj i ujedno najstariji tragovi kršćanstva na hrvatskim prostorima, te Splitu, gdje je u mauzoleju okrutnog rimskog cara Dioklecijana, progonitelja kršćana, niknula splitska katedrala u kojoj se nalazi sarkofag svetog Dujma, solinskog biskupa i mučenika (Petrač, Šanjek 1995: 380).

Dodatnu je potporu Hrvatskoj Sveti Otac dao i tijekom svoga trećeg posjeta Hrvatskoj, inače svog jubilarnog stotog apostolskog putovanja, u lipnju 2003. kada je pozornost svijeta skrenuo na čak 5 hrvatskih gradova u kojima je boravio - Rijeku, Dubrovnik, Osijek, Đakovo i Zadar. 
Papu je u Hrvatskoj pratilo oko 2.000 stranih novinara, a u tom trenutku to je bila glavna medijska atrakcija u Europi, pa se Hrvatska našla izložena očima europskih i svjetskih glasila (Bešker 2003: 15). Uz to, Sveti Otac je tijekom pohoda Hrvatskoj otvoreno lobirao za ulazak Hrvatske u Europsku uniju, ističući kako će „bogata hrvatska baština pridonijeti učvršćenju Unije, bilo kao upravne i teritorijalne cjeline, bilo pak kao kulturne i duhovne stvarnosti" (Papa u Hrvatskoj 2003b). Obraćajući se hrvatskoj javnosti prilikom dolaska na otok Krk 5. lipnja 2003., papa je podsjetio kako otok Krk čuva „,bogatu glagoljašku baštinu te kako je kršćanstvo u prošlosti dalo velik doprinos razvoju Hrvatske”. Istodobno ja zazvao blagoslov svetog Josipa, zaštitnika Hrvatske, te Blažene Djevice Marije „odvjetnice Hrvatske i najvjernije majke" (Nagy 2011: 451). Po povratku u Vatikan, na općoj audijenciji 11. lipnja 2013. papa je Dubrovnik opisao kao „stari i slavni grad, ponosan na svoju povijest i svoje tradicije slobode i pravde". U svojim govorima papa je često opisivao Hrvatsku kao plemenitu ${ }^{2}$, gostoljubivu i lijepu ${ }^{3}$.

\section{Zaključak}

U suvremenim međunarodnim odnosima i na sve konkurentnijem tržištu države se međusobno natječu za strane investicije, turiste, talentirane stanovnike, utjecaj u međunarodnim političkim institucijama i savezima, ali i globalnu medijsku pozornost. Zbog toga mnogobrojne države, preko vladinih institucija i agencija, nastoje sustavno upravljati vlastitim identitetom i imidžom, odnosno nacionalnom promocijom, te provode proces brendiranja (branding). Na taj način pokušavaju priskrbiti jaču prepoznatljivost u međunarodnoj javnosti te predstaviti svijetu svoje prednosti, vrednote, gospodarsku i turističku ponudu i sl. Pritom nerijetko biraju domaće ili inozemne „glasnike”, koji ih s najviše kredibiliteta, uvažavanja ili prihvaćenosti u javnosti mogu predstaviti svijetu. Međutim, percepcija o pojedinim državama najčešće ne nastaje u planiranim i kontroliranim

\footnotetext{
${ }^{2}$ Npr. opća audijencija u Vatikanu, 11. lipnja 2003.

${ }^{3} \mathrm{Npr}$. papin govor novom veleposlaniku Republike Hrvatske dr. Emiliju Marinu prigodom predaje vjerodajnica u posebnoj audijenciji u Vatikanu, 11. prosinca 2004.
} 
uvjetima, već globalne institucije ili pojedinci mogu mimo volje pojedinih država utjecati na njihov imidž plasiranjem određenih informacija ili stajališta, pozitivnog ili negativnog predznaka. Tome su podložnije one države koje ne rade dovoljno na vlastitom predstavljanju svijetu. Naime, tada postoji opasnost da to učini netko drugi umjesto njih, odnosno da budu „etiketirani” bez njihove volje i znanja. Takav pristup nazivamo „,vanjskim brendiranjem". Na taj problem upozorava britanski teoretičar Simon Anholt (2007), koji tvrdi da ćemo, ako ne pružimo dovoljno informacija o sebi, ustupiti mjesto dezinformacijama ili će inozemno javno mišljenje prihvatiti drugo relevantno stajalište o nama, iz nekog drugog izvora, koje nužno ne mora biti blagonaklono. Različiti su načini takvog „vanjskog brendiranja" i mogu ih provoditi mnogobrojni subjekti - od međunarodnih financijskih institucija i svjetskih državnika do medija, filmske industrije i poznatih pojedinaca.

Papa Ivan Pavao II. bio je jedan od najutjecajnijih ljudi dvadesetog stoljeća. Zahvaljujući svojoj poziciji poglavara Katoličke crkve, ali i svojoj karizmi te ponašanju i komunikacijskim sposobnostima, plijenio je pozornost globalne javnosti i smatran je jednim od najvećih autoriteta suvremenog svijeta. Zahvaljujući tome uvelike je utjecao na otvaranje različitih tema u javnosti, rješavanje društvenih problema, skretanje pozornosti na određene skupine, pojedince, pa i države. Promatrajući njegovo djelovanje u kontekstu vanjskog brendiranja, možemo zaključiti kako je uvelike pomogao pojedinim državama i nacijama u izvlačenju iz anonimnosti, promicanju njihovih posebnosti i vrijednosti te predstavljanju svijetu, a ponajprije katoličkoj javnosti. Sagledavajući djelovanje pape Ivana Pavla II. prema hrvatskom narodu, sasvim je jasno kako je svojim izravnim angažmanom uvelike pomogao pri međunarodnom priznanju Hrvatske te kako je pridonio predstavljanju i promociji Hrvata u globalnoj javnosti, posebice $u$ vrijeme jugoslavenskog komunističkog režima te tijekom stasanja hrvatske države, kad se o Hrvatima premalo znalo, a kada sami nisu bili u mogućnosti kvalitetno se predstaviti svijetu.

Hrvatski identitet i osobito povijest hrvatskoga naroda bili su omiljena tema pape Ivana Pavla II. kroz koje je nastojao svijetu predstaviti hrvatski narod kao vjernog saveznika Svete Stolice, a njih same podsjetiti na bogatu baštinu koja obvezuje. Govoreći i pišući o hrvatskom identitetu, papa je redovito podsjećao kako su Hrvati stari slavenski narod, odnosno 
prvi slavenski narod koji je prihvatio kršćanstvo. Isto tako je ukazivao na osviještenost ranih hrvatskih vladara da se od Bizanta okrenu Rimu i prihvate savez s Kristovim namjesnikom. Papa Hrvate prikazuje i kao vjerne saveznike Svete Stolice koji su to ostali stoljećima, unatoč mnogobrojnim izazovima. S time je povezana i teška sudbina, odnosno patnička prošlost hrvatskoga naroda, na koju papa redovito podsjeća, ali i goleme žrtve za više ideale, pa i obranu Europe. Papa se ne libi prikazati hrvatski narod i kao žrtve komunističkog režima te zala fašizma i nacizma, čijim simbolom smatra zagrebačkog nadbiskupa blaženog Alojzija Stepinca.

U njegovim govorima i porukama iščitavamo i snažnu poveznicu hrvatskog naroda i Majke Božje, odnosno istinsku pobožnost i odanost Gospi, te s tim u vezi sličnosti između Hrvata i Poljaka. Hrvate također predstavlja kao narod s bogatim kulturnim nasljeđem, tradicijom i običajima, ali i iseljenički narod. Ističući kontinuirano Hrvate kao stari slavenski narod, papa ih predstavlja i kao narod, odnosno državu koja je predodređena da povezuje istok i zapad, odnosno različite kulture i vjere. Papa je u svojim istupima svjestan i tranzicije kroz koju je prolazilo hrvatsko društvo posljednjih desetljeća te ukazuje na suvremene elemente identiteta, posebice u kontekstu demokratizacije i europskih integracija. U svakom slučaju papa Ivan Pavao II. pokazuje se jednim od boljih poznavatelja hrvatskog identiteta te jednim od najvećih i najutjecajnijih promotora toga identiteta među svjetskim velikanima.

\section{Literatura}

Anholt S., 2007, Konkurentan identitet, Zagreb.

Bešker I., 2003, Prestali smo biti zemlja senzacija i to je uspjeh, „Jutarnji list” 6. lipnja, str. 15.

Bešker I., 2005, To je bio Ivan Pavao II., Zagreb.

Körbler J., 2005, Wojtyla \& Ratzinger, svetac i filozof, Zagreb.

Kuharić F., 1994, Papa Ivan Pavao II. zadužio hrvatski narod, u: S. Tomašević, G. Galazka, Ivan Pavao II., Zagreb-Roma, str. 5.

Malović S., 1993, Image hrvatskih medija u svijetu, doktorska dizertacija, Varaždin.

Miličević K., Skoko B., Krešić D., 2012, The Power of Tourism in Creating a National Brand: The Case of Croatia, $\mathrm{u}$ : Destination Branding \& Marketing IV, ur. V. Richards, Cardiff, str. 236-247.

Mlivončić I., 1993, Pape i Hrvati, Zagreb. 
Nagy B., (ur.), 2011, Papa Ivan Pavao II. govori Hrvatima, Zagreb.

Papa u Hrvatskoj, 2003a, <www.papa.hr>, 21 svibnja 2003

Papa u Hrvatskoj, 2003b, <www.papa.hr/gover>, 20 srpnja 2003.

Pavičić D., 2005, Papa i Hrvati, Zagreb.

Petrač B., Šanjek F., (ur.), 1995, Ivan Pavao II. i Hrvati, Zagreb.

Pintarić N., 1999, Bistrički hodočasnik, Zagreb.

Rukavina K., 2003, Hrvati Papi - Papa Hrvatima, Rijeka.

Sanader I., 2000, Hrvatska u međunarodnim odnosima, Zagreb.

Skoko B., 2003, Hrvatska - identitet, image, promocija, Zagreb.

Tomašević S., 2009, Dvojica papa - Ivan Pavao II. i Benedikt XVI., Zagreb.

Tomašević S., Galazka G., 1994, Ivan Pavao II., Zagreb-Roma. 